\title{
SENSE OF CONTROL, SATISFACTION WITH LIFE AND STRESS COPING STYLES OF FLIGHT STAFF
}

\author{
Anna TURBACZ1 , Zdzisław KOBOS ${ }^{1,2}$ \\ ${ }^{1}$ Cardinal Stefan Wyszynski University, Institute of Psychology, Warsaw, Poland \\ ${ }^{1,2}$ Regional Military Aviation Medicine Commission in Warsaw, Warsaw, Poland
}

Source of support: Own sources

Author's address: A. Turbacz, Cardinal Stefan Wyszynski University in Warsaw, Institute of Psychology, Dewajtis 5 Street, 01-815 Warsaw, Poland, e-mail: turbacza@o2.pl

Introduction: The aim of this study is to examine the relationship between the sense of control, life satisfaction and stress coping styles, and whether there are any differences between air traffic controllers and pilots in these variables.

Methods: 80 men were tested, including 40 military pilots and 40 air traffic controllers. The tests were carried out with the use of: Satisfaction with Life Scale (SWLS/) - authors: Ed Diener, Robert A. Emmons, Randy J. Larson, Sharon Griffin, the Survey for Measurement of the Sense of Control /Delta/- by R. Ł. Drwal, The Coping Inventory for Stressful Situations /CISS/ - by N. S. Endler, J.D.A. Parker.

Results: On the basis of statistical analyses, no differences were found between pilots and air traffic controllers in the sense of location of control. Compared to air traffic controllers, pilots achieve significantly higher results in the case of the avoidance style and its subdimensions, i.e. surrogate activities and looking for social contacts as a form of coping with stress. In addition, the group of pilots found a significant positive relationship between life satisfaction and the search for social contacts, while the group of controllers found a significant moderate negative relationship between life satisfaction and the emotional stress coping style.

Keywords: stress coping styles, sense of control, life satisfaction, air traffic controllers, pilots

Tables: 6 - References: 17 • Full-text PDF: http://www.pjambp.com • Copyright (C 2017 Polish Aviation Medicine Society, ul. Krasińskiego 54/56, 01-755 Warsaw, license WIML • Indexation: Index Copernicus, Polish Ministry of Science and Higher Education 


\section{INTRODUCTION}

Occupations associated with aviation involve responsibility for one's health and life and that of others both in the air and on the ground, as is the case in the event of an accident or catastrophe. Therefore, in order to ensure maximum safety of air missions, as early as in 1928 obligatory medical and psychological examinations of candidates for aviation were introduced in our country.

The assessment of the psychophysical fitness of aviation applicants shall be carried out by specialist aviation medicine committees composed of certified aviation medicine examiners and specialized psychologists. These specialists assess the suitability for a specific type of aviation or for specific jobs in aviation on the basis of subjective, objective, laboratory tests.

In order to monitor the health status of aviation personnel throughout their working lives, mandatory annual tests before an aviation medicine commission have also been introduced. In the case of health or professional problems, aviation personnel are referred to the aviation medicine committee for occasional examinations, the purpose of which is to find the reasons (health, psychological) for ineffective performance of tasks and to determine their current suitability for work in occupations associated with aviation.

In addition, the development of aviation technology and the increasing number of air operations are resulting in an increasing psychophysical burden in occupations associated with aviation. This is reflected in the dynamics of everyday life in society and generates stressful situations which, in order to ensure flight safety, require exploratory research in order to ensure efficiency and reliability in the performance of aviation tasks.

The knowledge gained from the conducted tests allows to improve diagnostic methods in such a way that it is possible to assess more accurately the professional predispositions of the aviation personnel and to forecast the operator reliability of pilots (flight crews) and air traffic controllers $[1,7,16]$.

As already mentioned, the working conditions in occupations associated with aviation can be considered as stressful situations (occupational stress), which sometimes also involves the need to act in non-standard situations, which may burden the human being both mentally and physically [16]. In the literature [12] on the subject, such situations are well explained, among others, by R. Lazarus's and S. Folkman's transactional concept of stress. These authors describe stress as "a special kind of relationship between humans and their environment, which they consider to be taxing or exceeding their resources and endangering his well-being" [12]. Stress situations encountered by people are usually triggered by activities aimed at improving ill emotional health and restoring a balance between the requirements and the possibilities of meeting them. Whereas the set of strategies, or dispositions, that are activated in a given stress situation, is defined as a style of coping with stress, and these are "constantly changing cognitive and behavioral efforts to manage specific external and internal requirements, assessed by a person as taxing or exceeding their resources" $[8,9,15]$. Therefore, coping with stress can be assigned with two functions. The first one is problem-oriented, focusing on improving relations between the entity and its environment, and is described as task-based. The second is the function of self-regulation of emotions, which consists in lowering unpleasant tension and alleviating other negative emotional states. The two functions or the trends of coping are not entirely separate and independent. In a specific stress situation, they interweave and interact with each other.

The authors of many studies $[12,13,15,16,17]$ also draw attention to the role of emotions in the process of coping with problems, which also play an important adaptational role. Namely, they indicate that something vital for the subject is going on, and also they energize the process of coping and shape its course. Therefore, self-regulation of emotions may reduce unpleasant tension, but it may also aim at increasing the mobilizing stimulus for action $[8,9]$. Referring to this concept, Endler and Parker [6] proposed three styles of stress management. In addition to the task- and emotion-focused styles proposed by Lazarus and Folkman [12], they propose a third way of dealing with stress, i.e. focusing on avoiding it. It is characterized by a tendency to avoid, survive and think about the risk in order to reduce the effects of the stressor [13]. The choice of the style of coping with stress depends on both the situation perceived as difficult and individual properties of a human being $[8,9]$. Amongst them one can list a variable of personality, which is the "location of the sense of control". Julian Rotter's "location of the sense of control" construct was presented in his work on social learning theory as a dimension of personality [8] and is expressed as a general expectation that one's own action is a tool to achieve one's goal. When experiencing reality, the human being influences the environment, anticipates its states and gradually creates in their cognitive system 
a picture of the basic relationship between themselves and their surroundings. The set of beliefs that makes up this image is called the sense of control [11]. In this way, a person develops a permanent, generalized expectation for the location of reinforcement control. It is an individual property of a human being which is perceived as a dimension of personality, a continuum with two opposite poles: a generalized sense of external control and a generalized sense of internal control $[4,5]$. If a person perceives an event as a consequence of their own actions, makes efforts to control their environment, takes responsibility for their own actions, searches for information, then this is the so-called sense of internal control. However, when they perceive events as the result of: chance, luck, destiny, we are dealing with a sense of external control [12].

Human stress is also related to life satisfaction, which affects professional efficiency. Stress may lead to the improvement of individual quality of life or reduce it, however, it depends on the subjective assessment of its intensity [12].

Ineffective performance of work, mistakes made, negative evaluation of professional activities result in a significant drop in satisfaction with life, causing insecurity and a lack of emotional stability.

The multiplicity of stressful effects of the working environment of pilots and air traffic controllers cannot be without consequences for physical or mental health. In this context, the problem of the satisfaction with life experienced by such professional groups is of particular importance. It is described in the literature on the subject as an overall assessment of satisfaction with one's own achievements and living conditions $[3,10]$. Such an understanding of life satisfaction refers to subjective indicators, i.e. the assessments of the person themselves, and not to objective indicators of the quality of life, and also includes them as cognitive assessment, evaluating judgment, and not an emotional condition.

The research also indicates that work may influence the satisfaction with its performance, when it is a source of pleasure, good interpersonal relations and serves to build a sense of meaningfulness in life [14].

These factors seem to be an area of research on the working environment of such specific occupational groups as pilots and air traffic controllers in terms of cognition and application, because of the high social responsibility for the fate of other people.
It should be stressed that the ineffective performance of the tasks of these professional groups can lead to air accidents or catastrophes, and that this has consequences both in terms of the media and in terms of personal and economic well-being.

The literature on psychological studies in the professional group of pilots and air traffic controllers is not very extensive. So far, no research has been carried out into the interrelationships between such variables as: the sense of control or satisfaction with life and the styles of coping with stressful situations in the above mentioned professional groups.

Many studies analyzing the relationship between stress management styles and personality can be found in Polish literature $[2,9,12,15,16,17]$. Numerous studies have been carried out over a period of several years, but with different testing methods. Moreover, it was not possible to find works in the available literature that would deal with the issues of control, satisfaction with life and styles of coping with work stress. The current work is exploratory in nature, and the results and analysis of the obtained results can be treated as a basis for further research.

The aim of this study is to examine the relationship between the sense of control, life satisfaction and stress coping styles, and whether there are any differences between air traffic controllers and pilots in these variables. Therefore, the aim of this paper is to answer the following research questions:

1. Are there differences between pilots and air traffic controllers in the sense of where control is located, in the way they deal with stress and in their sense of satisfaction with life?

2. Are there relationships between the sense of location of control and stress coping styles?

3. Are there any links between the sense of location of control and satisfaction with life?

4. Are there any links between life satisfaction and stress coping styles?

\section{METHODS}

80 people aged 23 to 41 were tested. This group consisted of 40 pilots and 40 air traffic controllers. The research took place at the Military Institute of Aviation Medicine and at the Polish Air Navigation Services Agency. Participation in the study was anonymous and voluntary. In the groups of pilots and controllers there is a similar number of persons with secondary and tertiary education. 
The following research tools were used in the studies:

1. The Survey for Measurement of the Sense of Control /Delta/ - by Radosław Ł. Drwal [4].

2. Satisfaction with Life Scale (SWLS) - authors: Ed Diener, Robert A. Emmons, Randy J. Larson, Sharon Griffin (Polish adaptation by Z. Juczyński) [10].

3. The Coping Inventory for Stressful Situations (CISS) - authors: N. S. Endler, J. D. A. Parker (Polish adaptation by P. Szczepaniak, J. Strelau and K. Wrześniewski) [6].

\section{RESULTS}

In order to verify the differences between the pilots and the controllers in the sense of location of control /Delta/, a comparison of the averages between the examined groups was made. Due to the fact that the variables describing the location of control and the lie scale in the Delta test did not have a normal distribution, the analysis was carried out using a nonparametric Mann-Whitney U-rank test ${ }^{1}$. Belonging to the above mentioned occupational groups was introduced as a grouping variable, while the analyzed variables included the sense of location of control and results in the lie scale. The obtained data have been presented in table 1.

Tab. 1. Comparison of the location of control between pilots and air traffic controllers.

\begin{tabular}{|c|c|c|c|c|c|c|}
\hline Parameter & $\begin{array}{c}\text { Group } \\
\text { of professionals }\end{array}$ & $\begin{array}{c}\text { Average } \\
\text { ranks } \\
\text { (Rs) }\end{array}$ & (Sd) & z & $\mathrm{n}$ & $\begin{array}{c}\text { Significance } \\
\text { (bilateral) }\end{array}$ \\
\hline \multirow{2}{*}{$\begin{array}{l}\text { Location } \\
\text { of control }\end{array}$} & Pilots & 3.13 & 2.45 & \multirow{2}{*}{-0.990} & 40 & \multirow{2}{*}{0.322} \\
\hline & Controllers & 3.48 & 2.12 & & 40 & \\
\hline \multirow{2}{*}{ Lie Scale } & Pilots & 2.20 & 1.52 & \multirow{2}{*}{-1.003} & 40 & \multirow{2}{*}{0.316} \\
\hline & Controllers & 1.85 & 1.35 & & 40 & \\
\hline
\end{tabular}

Legend: Z - test statistics, Sd - standard deviation, Rs - average ranks, $\mathrm{n}$ - number of people tested

On the basis of the Mann-Whitney $U$ test, the differences on the "sense of location of control" scale between the flight controllers and the pilots proved to be statistically insignificant $Z=-0.090$, $p=0.322$.

One then also sought to determine whether the pilots differed from the air traffic controllers in the severity of the specific "styles and stress management" used (table 2) and the perceived "satisfaction with life" (table 3). For this purpose, a comparison of the averages between the two groups

1 The Mann-Whitney $U$ test is used when you want to compare two independent samples. It is considered to be the non-parametric equivalent of the Student's parametric t-test for independent samples. of the Student's t-test for two independent groups was made.

Tab. 2. Comparison of stress management styles between a group of tested pilots and air traffic controllers.

\begin{tabular}{|c|c|c|c|c|c|c|}
\hline $\begin{array}{l}\text { Mana- } \\
\text { gement } \\
\text { style }\end{array}$ & $\begin{array}{c}\text { Group } \\
\text { of professionals }\end{array}$ & (M) & (Sd) & $t$ & Df & $\begin{array}{c}\text { Significance } \\
\text { (bilateral) }\end{array}$ \\
\hline \multirow{2}{*}{$\begin{array}{l}\text { Task- } \\
\text {-oriented }\end{array}$} & Pilots & 58.10 & 7.87 & \multirow{2}{*}{-2.194} & \multirow{2}{*}{78} & \multirow{2}{*}{0.031} \\
\hline & Controllers & 61.95 & 7.83 & & & \\
\hline \multirow{2}{*}{ Emotional } & Pilots & 35.10 & 9.85 & \multirow{2}{*}{0.674} & \multirow{2}{*}{78} & \multirow{2}{*}{0.502} \\
\hline & Controllers & 33.68 & 9.05 & & & \\
\hline \multirow{2}{*}{ Avoidance } & Pilots & 45.75 & 9.19 & \multirow{2}{*}{4.138} & \multirow{2}{*}{78} & \multirow{2}{*}{0.001} \\
\hline & Controllers & 36.73 & 10.29 & & & \\
\hline \multirow{2}{*}{$\begin{array}{l}\text { Surrogate } \\
\text { activities }\end{array}$} & Pilots & 19.80 & 5.47 & \multirow{2}{*}{3.789} & \multirow{2}{*}{78} & \multirow{2}{*}{0.001} \\
\hline & Controllers & 14.63 & 6.69 & & & \\
\hline \multirow{2}{*}{$\begin{array}{l}\text { Social } \\
\text { contacts }\end{array}$} & Pilots & 17.08 & 3.69 & \multirow{2}{*}{2.923} & \multirow{2}{*}{78} & \multirow{2}{*}{0.005} \\
\hline & Controllers & 14.80 & 3.26 & & & \\
\hline
\end{tabular}

Legend: $\mathrm{M}$ - arithmetic average, $\mathrm{t}$ - test statistics, $\mathrm{Sd}$ - standard deviation, Df - degrees offreedom

The result of the conducted analysis turned out to be politically significant $t(78)=-2.194 ; p=0.031$ between the groups examined in relation to the task-oriented style. In this respect, air traffic controllers achieved significantly higher results $(M=61.95)$, while persons from the group of pilots $(M=58.10)$ had lower results. Also the groups studied differed significantly in terms of statistics on the use of the "avoidance style". $[\mathrm{t}(78)=4.138$; $\mathrm{p}<0.001]$ and its subdimensions, i.e. "surrogate activities" [t(78)=3.798; $\mathrm{p}<0.001]$ and "seeking social contacts" $[\mathrm{t}(78)=2.923 ; \mathrm{p}=0.005]$. The results shown in Table 2 show that pilots achieved significantly higher values than air traffic controllers in this dimension. The assessment of satisfaction with life is in turn presented in table 3.

Tab. 3. Comparison of the level of satisfaction with life between professional groups.

\begin{tabular}{lccccccc}
\hline Parameter & $\begin{array}{c}\text { Group } \\
\text { of professionals }\end{array}$ & $\begin{array}{c}\text { Mean } \\
\text { (M) }\end{array}$ & $\begin{array}{c}\text { Standard } \\
\text { deviation } \\
\text { (Sd) }\end{array}$ & t & Df & $\begin{array}{c}\text { Signi- } \\
\text { ficance } \\
\text { (bilateral) }\end{array}$ \\
\hline $\begin{array}{l}\text { Satisfac- } \\
\text { tion with } \\
\text { life }\end{array}$ & Pilots & 24.35 & 4.46 & & & \\
\cline { 2 - 5 } & Controllers & 23.30 & 4.08 & & 78 & 0.276 \\
\hline
\end{tabular}

Legend: $\mathrm{M}$ - arithmetic average, $\mathrm{t}$ - test statistics, Sd - standard deviation, Df - degrees offreedom

Both occupational groups indicated a similar level of satisfaction with life. For the pilots the average satisfaction was $\mathrm{M}=24.35, \mathrm{Sd}=4.46$, for the controllers $\mathrm{M}=23.30$; $\mathrm{Sd}=4.08$.

A correlation analysis has been carried out to see if there is a relationship between the sense of location of control and stress management styles. Due to the fact that the variable describing the sense of location of control did not get a normal 
Turbacz A. et al. - Sense of control...

distribution, the analysis used the non-parametric Spearman's rho rank correlation coefficient. The analysis was conducted for both groups together and separately for the group of pilots and the air traffic controllers. The analysis results are presented in table 4.

Tab. 4. Relationships between the sense of location of control and stress coping styles.

\begin{tabular}{|c|c|c|c|c|}
\hline \multirow[b]{2}{*}{ Management style } & \multirow[b]{2}{*}{ Parameter } & \multicolumn{3}{|c|}{ Group of professionals } \\
\hline & & Total & Pilots & Controllers \\
\hline \multirow{2}{*}{ Task-oriented } & $\begin{array}{l}\text { Correlation } \\
\text { coefficient }\end{array}$ & -0.356 & -0.554 & -0.247 \\
\hline & $\begin{array}{l}\text { Significance } \\
\text { (bilateral) }\end{array}$ & 0.001 & 0.001 & 0.125 \\
\hline \multirow{2}{*}{ Emotional } & $\begin{array}{l}\text { Correlation } \\
\text { coefficient }\end{array}$ & 0.188 & 0.133 & 0.169 \\
\hline & $\begin{array}{l}\text { Significance } \\
\text { (bilateral) }\end{array}$ & 0.095 & 0.415 & 0.297 \\
\hline \multirow{2}{*}{ Avoidance } & $\begin{array}{l}\text { Correlation } \\
\text { coefficient }\end{array}$ & 0.151 & 0.115 & 0.222 \\
\hline & $\begin{array}{l}\text { Significance } \\
\text { (bilateral) }\end{array}$ & 0.182 & 0.481 & 0.168 \\
\hline \multirow{2}{*}{ Surrogate activities } & $\begin{array}{l}\text { Correlation } \\
\text { coefficient }\end{array}$ & 0.169 & 0.116 & 0.219 \\
\hline & $\begin{array}{l}\text { Significance } \\
\text { (bilateral) }\end{array}$ & 0.133 & 0.475 & 0.175 \\
\hline \multirow{2}{*}{ Social contacts } & $\begin{array}{l}\text { Correlation } \\
\text { coefficient }\end{array}$ & 0.024 & 0.071 & 0.129 \\
\hline & $\begin{array}{l}\text { Significance } \\
\text { (bilateral) }\end{array}$ & 0.834 & 0.664 & 0.427 \\
\hline
\end{tabular}

On the basis of the conducted analysis, a significant negative moderate relationship between the "sense of location of control" and the "taskoriented stress management style" was found in the group of pilots.

Next, the relationships between the "location of control" and "satisfaction with life" were analyzed. As before, the analysis was conducted for both groups together and separately for the group of pilots and the air traffic controllers. The analysis results are presented in table 5 .

Tab. 5. Relationships between the sense of location of control and satisfaction with life.

\begin{tabular}{llccc}
\hline & & \multicolumn{3}{c}{ Group of professionals } \\
\cline { 2 - 5 } & Parameter & Total & Pilots & Controllers \\
\hline \multirow{3}{*}{$\begin{array}{l}\text { Satisfaction } \\
\text { with life }\end{array}$} & Correlation coefficient & -0.019 & -0.175 & -0.080 \\
\cline { 2 - 5 } & Significance (bilateral) & 0.868 & 0.279 & 0.623 \\
\cline { 2 - 5 } & $\begin{array}{c}\text { Number of research } \\
\text { subjects }\end{array}$ & 80 & 40 & 40 \\
\hline
\end{tabular}

The results of the research indicate that there were no statistically significant relationships between the "sense of location of control" and "satisfaction from life" in the groups we studied.

The linear Pearson r correlation coefficient was used to check the relationship between "satisfaction with life" and "stress management styles".
Tab. 6. Relationships between life satisfaction and stress coping styles.

\begin{tabular}{|c|c|c|c|c|}
\hline \multirow{2}{*}{$\begin{array}{l}\text { Management } \\
\text { style }\end{array}$} & \multirow[b]{2}{*}{ Parameter } & \multicolumn{3}{|c|}{ Group of professionals } \\
\hline & & Total & Pilots & Controllers \\
\hline \multirow{2}{*}{ Task-oriented } & $\begin{array}{l}\text { Pearson's } \\
\text { correlation }\end{array}$ & 0.037 & 0.114 & 0.020 \\
\hline & $\begin{array}{l}\text { Significance } \\
\text { (bilateral) }\end{array}$ & 0.748 & 0.485 & 0.904 \\
\hline \multirow{2}{*}{ Emotional } & $\begin{array}{l}\text { Pearson's } \\
\text { correlation }\end{array}$ & -0.308 & -0.231 & -0.427 \\
\hline & $\begin{array}{l}\text { Significance } \\
\text { (bilateral) }\end{array}$ & 0.006 & 0.152 & 0.006 \\
\hline \multirow{2}{*}{ Avoidance } & $\begin{array}{l}\text { Pearson's } \\
\text { correlation }\end{array}$ & 0.015 & 0.136 & -0.216 \\
\hline & $\begin{array}{l}\text { Significance } \\
\text { (bilateral) }\end{array}$ & 0.897 & 0.403 & 0.181 \\
\hline \multirow{2}{*}{$\begin{array}{l}\text { Surrogate } \\
\text { activities }\end{array}$} & $\begin{array}{l}\text { Pearson's } \\
\text { correlation }\end{array}$ & -0.058 & 0.026 & -0.247 \\
\hline & $\begin{array}{l}\text { Significance } \\
\text { (bilateral) }\end{array}$ & 0.608 & 0.873 & 0.124 \\
\hline \multirow{2}{*}{ Social contacts } & $\begin{array}{l}\text { Pearson's } \\
\text { correlation }\end{array}$ & 0.179 & 0.327 & -0.070 \\
\hline & $\begin{array}{c}\text { Significance } \\
\text { (bilateral) }\end{array}$ & 0.111 & 0.040 & 0.666 \\
\hline
\end{tabular}

In the group of pilots there was a significant positive weak relationship between "satisfaction with life" and "seeking for social contacts". On the other hand, the group of controllers had a significant negative moderate relationship between "satisfaction with life" and "emotional stress management style". The above table also shows that no statistically significant correlations with satisfaction with life in the studied groups of professional pilots and air traffic controllers were found with respect to the task-oriented and avoidance styles, as well as with respect to surrogate activities.

\section{DISCUSSION}

The studies show that there are no differences between the pilots and the air traffic controllers in the sense of location of control. It should be stressed that the groups were similar in terms of variables such as age, gender and education. The lack of differences in intensity of this characteristic may indicate homogeneity of the studied groups and similarity of professional burdens in both pilots and air traffic controllers. This leads to the conclusion that both professional groups perceive their own behavior and what is happening in their professional environment as dependent on them and not on chance or on other people. According to the literature, an internal sense of control [16] is the most conducive to efficient operation and taking up challenges. Thus, it is a desirable personality trait for both pilots and air traffic controllers. Namely, by being convinced that they have an impact on their own lives, people with such 
characteristics can take dynamic, independent and effective action, especially in stressful situations, and they can be very active in searching for information, using their previously acquired knowledge to solve problems.

The results of analyses of the above mentioned professional groups, which refer to preferred styles of coping with stress (i.e. task-oriented and avoidance-oriented), significantly differentiate these groups in statistical terms. Thus, in relation to the avoidance style and its subdimensions, i.e. surrogate activities and seeking social contacts, as a form of coping with stress, the group of pilots achieved significantly higher results in comparison with the group of air traffic controllers. On the other hand, no significant statistical dependencies were found in the compared professional groups in terms of preference for the emotional style of coping with stress.

The analysis also showed differences between the two groups in their preference for the avoidance-oriented style and its subdimensions in terms of seeking social contacts and engaging in surrogate activities. In these dimensions, the pilots score significantly higher than the air traffic controllers. It is likely that, although they manage stressful situations such as the pilot profession efficiently, they tend to avoid thinking, re-living and repeatedly experiencing difficult situations. They have to solve problems they may encounter in the air on an ongoing basis and additionally have in mind the responsibility they bear for the safety of passengers with whom they fly. The avoidance style of coping with stress in this case may play an adapational role in solving short-term problems than in the case of chronic stress [12].

On the other hand, the comparison of pilots with air traffic controllers in terms of perceived life satisfaction did not indicate any significant statistical differences between them. It can be deduced from this that two groups so similar in professional terms may feel a similar level of satisfaction with life. As the previous analysis of the variables has shown, the difference in average results between the two groups is minimal, which may be related, among other things, to the similarity of their choice of a profession related to aviation and a common five-year educational and pedagogical path at an aviation college.

The next step was to identify the relationships that may exist in the sense of location of control with the choice of preferred stress management styles. The results showed that there is a significant negative relationship between the sense of location of control and the stress management style of the pilots. This means that the higher the results of the pilots regarding the external sense of control, the less the task-oriented stress management style is preferred. The study did not establish a link between the sense of location of control and the choice of other stress management styles. People with an internal sense of control over reinforcements in the face of threatening situations make an effort to solve the situation constructively, rather than to focus on their own emotions and experiences. The internal sense of control of reinforcement is connected with the belief in their own ability to control everyday situations and with high self-esteem, which can be useful when practicing such a dangerous profession. The literature [16] indicates that perceiving one's own control over events experienced in life remains a coincidence with better mental wellbeing. People looking for factors that shape their fate outside themselves, cope with stress much worse than those who claim to be the authors of events [2]. The internal subjective belief of a human being that they can control their difficulties makes them treat a given situation as a challenge, which involves taking more efficient action to reduce the negative tension caused by stress.

On the other hand, the lack of links between the sense of control and other stress management styles may indicate that coping with difficult situations may be determined by situational factors rather than personality factors.

On the basis of the conducted research, it was not possible to determine the relationship between the sense of location of control and the perceived satisfaction with life. This could mean that the location of control may not affect the subjectively perceived satisfaction with life in the analyzed groups.

Effective management of stress is one of the indicators of satisfaction with life, according to research. The analysis of the obtained dependencies revealed a statistically significant weak positive relationship between the satisfaction with life and seeking social contacts in the pilots. The air traffic controllers have been shown to have a significant negative moderate relationship between satisfaction with life and the emotional stress management style.

The higher the scores of the pilots in the perceived satisfaction with life, the higher the score in the social contacts scale as an avoidance stress management style. For the air traffic controllers, however, the results show that the higher their results are on the satisfaction scale, the lower is their score in the emotional stress management style. 
One of the factors from which people gain satisfaction is their own activity and contacts with other people. Close relationships with others, belonging to a group can help to overcome stressful events and thus effectively contribute to an increase in the quality of life. Through contacts with others, pilots can try to reduce emotional states, analyze the stressful situations in which they may find themselves, and obtain social support for their actions. Such strategies may have a mobilizing function and direct the course of remedial action [12].

Faced with stressful situations, air traffic controllers focus on actions aiming at addressing the problem by changing the situation or by cognitively transforming it. The solution of problems reduces negative emotions and contributes to sensing positive emotions, which can become a source of a sense of satisfaction with life. As the theory of building and broadening positive emotions says, experiencing positive emotions increases creativity and the ability to think, which is the reason for choosing more effective strategies for dealing with stress [12].

The research carried out has made it possible, to some extent, to characterize specific professional groups, such as pilots and air traffic controllers. Moreover, the results were used to determine whether there are relationships between such variables as: the sense of control, satisfaction with life and the styles of coping with stress. The results presented above and the conclusions may serve as an inspiration to undertake further research in order to characterize such specific occupations, which are considered to be one of the most responsible and stressful.

\section{CONCLUSIONS}

No statistically significant differences were found between the pilots and the air traffic controllers in the sense of location of control.

Pilots achieve slightly higher results in the case of applying the avoidance style and its subdimensions, i.e. surrogate activities and looking for social contacts as a form of coping with stress.

There were no significant statistical differences between the two groups in terms of satisfaction with life.

There was a significant positive weak relationship between "satisfaction with life" and "seeking for social contacts" in the pilots.

The group of controllers had a significant negative moderate relationship between "satisfaction with life" and "emotional stress management style".

\section{AUTHORS' DECLARATION:}

Study Design: Anna Turbacz, Zdzisław Kobos; Data Collection: Anna Turbacz, Manuscript Preparation: Anna Turbacz, Zdzisław Kobos; Funds Collection: Anna Turbacz, Zdzisław Kobos. The Authors declare that there is no conflict of interest.

\section{REFERENCES}

1. Campbell J, O'Connor P. Coping with stress in military aviation: A review of the research. In: P. O'Connor \& J. Cohn (Eds.). Human Performance Enhancements in High-Risk Environments: Insights Developments, and Future Directions from Military Research, Santa Barbara, CA: ABC- Clio. 2010:169-188.

2. Czapiński J. Osobowość szczęśliwego człowieka, (w:) Czapiński J, (red.:) Psychologia pozytywna, Nauka o szczęściu, zdrowiu, sile i cnotach człowieka. Wydawnictwo PWN; Warszawa. 2004:359-379.

3. Diener E, Emmons RA, Larsen RJ, Griffin S. The Satisfaction With Life Scale. Journal of Personality Assessment. 1985; 49:71-75.

4. Drwal RŁ. Opracowanie kwestionariusza Delta do pomiaru poczucia kontroli. Studia Psychologiczne. 1979; 18(1):67-84.

5. Drwal RŁ. Techniki kwestionariuszowe w diagnostyce psychologicznej - wybrane zagadnienia. Lublin, Uniwersytet Marii Curie-Skłodowskiej. 1989; 120-253.

6. Endler NSJ, Parker DA. CISS - Kwestionariusz Radzenia Sobie w Sytuacjach Stresowych, polska adaptacja Piotr Szczepaniak, Jan Strelau, Kazimierz Wrześniewski, Wyd. Pracownia Testów Psychologicznych, Warszawa. 2005; 16-17, 21-25, 69-72.

7. Galster, SM, Duley JA, Masalonis AJ, Parasuraman R. Air traffic controller performance and workload under mature free flight: Conflict detection and resolution of aircraft self-separation . International Journal of Aviation Psychology. 2001:11, 71-93. 
8. Heszen-Niejodek I. Teoria stresu psychologicznego, (w:) J. Strelau (ed.): Psychologia-Podręcznik akademicki. Gdańsk: GWP. 2000:465-492.

9. Heszen-Niejodek I. Stres i radzenie sobie: główne kontrowersje. (w:) Heszen-Niejodek I, Ratajczak Z. (red.): Człowiek w sytuacji stresu: Problemy teoretyczne i metodologiczne. Katowice: Wydawnictwo Uniwersytetu Śląskiego. 2000:12-43.

10. Juczyński Z. Narzędzia pomiaru w promocji i psychologii zdrowia (Skala Satysfakcji z Życia-SWLS, autorstwa: Diener Ed, Emmons Robert A, Randy J. Larson, Sharon Griffin, adaptacja: Zygfryd Juczyński), Wydawnictwo: Pracowania Testów Psychologicznych, Warszawa. 2009:128-133.

11. Kofta M. Kontrola psychologiczna nad otoczeniem. Psychologia Wychowawcza. 1977; 20(2):150-167.

12. Lazarus RS, Folkman S. Stress, appraisal and coping. New York: Springer Publishing Co. 1984; 11-21, 456.

13. Ogińska-Bulik N, Juszczyński Z. Osobowość, Stres a Zdrowie. Warszawa: Difin. 2008; 46-93, $169-298$.

14. Skrzypińska K. Pogląd na świat a poczucie sensu i zadowolenie z życia. Kraków: Impuls. 2002; 67-296.

15. Terelak JF. Psychologia stresu, Wydawnictwo Branta, Bydgoszcz. 2001; 69-73.

16. Terelak JF, Podolak G, Rudzcki A. Kontrolerzy ruchu lotniczego. (w:) Terelak JF, red. Stres zawodowy. Warszawa: UKSW. 2007:141-155.

17. Terelak JF, Stefańczyk A. Osobowość według „Wielkiej Piątki” a Style Radzenia Sobie ze Stresem u Kontrolerów Ruchu Lotniczego. Polski Przegląd Medycyny Lotniczej. 2010; 16(2):131-140.

\section{ACKNOWLEDGEMENTS}

The views, opinions, and findings contained in this article are our own and should not be construed as an official Polish Air Force position, policy, or decision, unless so designated by other official documentation.

Cite this article as: Turbacz A, Kobos Z. Sense of Control, Satisfaction wth Life and Stress Coping Styles of Flight Staff . Pol J Aviat Med Bioeng Psychol 2017; 23(2): 11-18. DOI: 10.13174/ pj ambp. 16.07.2018. 02 